\title{
MATRIX METALLOPROTEINASES AND THEIR FUNCTION IN MYOCARDIUM
}

\author{
Jiř́i Kukačka ${ }^{\mathrm{a}, \mathrm{b}}$, Richard Průša ${ }^{\mathrm{a}}$, Karel Kotaška ${ }^{\mathrm{a}}$, Václav Pelouch ${ }^{\mathrm{b}}$ \\ a Department of Clinical Biochemistry and Pathobiochemistry Faculty Hospital Motol and $2^{\text {nd }}$ Medical Faculty of Charles \\ University \\ ${ }^{b}$ Department of Medical Chemistry and Biochemistry of Charles University, $2^{\text {nd }}$ Medical Faculty, Prague, Czech Republic
}

Received: June 10, 2005; Accepted: September 25, 2005

Key words: Extracellular matrix/Matrix metalloproteinases (MMPs)/Myocardium/Remodeling/MMP inhibitors

\begin{abstract}
A significant number of myocardial diseases are accompanied by increased synthesis and degradation of the extracellular matrix (ECM) as well as by changed maturation and incorporation of ECM components. Important groups of enzymes responsible for both normal and pathological processes in ECM remodeling are matrix metaloproteinases (MMPs). These enzymes share a relatively conserved structure with a number of identifiable modules linked to their specific functions. The most important function of MMPs is the ability to cleave various ECM components; including such rigid molecules as fibrillar collagen molecules. The amount and activity of MMPs in cardiac tissue are regulated by a range of activating and inhibiting processes. Although MMPs play multifarious roles in many myocardial diseases, here we have focused on their function in ischemic cardiac tissue, dilated cardiomyopathy and hypertrophied cardiac tissue. The inhibition of MMPs by means of synthetic inhibitors seems to be a promising strategy in cardiac disease treatment. Their effects on diseased cardiac tissue have been successfully tested in several experimental studies.
\end{abstract}

\section{INTRODUCTION}

Matrix metalloproteinases or matrixins (MMPs) represent a family of structurally related enzymes that belong to the large group of zinc-dependent metallopeptidases, sometimes called metzincins. Metzincins can be divided into 4 groups according to their mode of zinc binding - astacins, reprolysins (ADAMs enzymes), serralysins and matrixins. MMPs have been found in both vertebrates, and invertebrates, and even in plants. Evolutionarily, however, they developed from far lower organisms as protein sequence homology showes that amino acid sequence for metalloproteinase toxin-2 of Bacteroides fragilis has $59 \%$ homology with 27 amino acid chain of human interstitial collagenase (MMP-1)( ref. $\left.^{1}\right)$. These enzymes not only take part in biological processes, such as degradation of connective tissue, and ontogenesis (morphogenesis, angiogenesis, growth), but also processes associated with wound healing ${ }^{2-4}$. Changes in MMP expression and activity can be observed in most inflammatory, degenerative, and especially malign processes associated with increased synthesis, degradation or impaired maturation and organization of extracellular matrix $(\mathrm{ECM})\left(\right.$ ref. $\left.^{5-8}\right)$. There are also other enzymes, such as cystyl- and seryl-proteases group and other metallopeptidases participating in ECM degradation. 24 human matrix metalloproteinases were known at the time of preparing this review ( abbreviated MMP plus an Arabic numeral). The overview of MMPs is listed in Table 1.

\section{STRUCTURE OF MATRIX METALLOPROTEINASES}

Matrix Metalloproteinases are homologous proteins which can be divided into 6 groups according to their common features: collagenases, stromelysins, matrilysins, gelatinases, membrane-type metalloproteinases (MT-MMPs) and other MMPs, namely zinc- and calcium-dependent endopeptidases. While the classification to 6 basic groups is probably the most known among sciences, they have been published other classifications e.g. a) classification based on solubility: soluble MMPs, membrane-associated MMPs and CA (cystein array) MMP; b) classification into 9 subgroups on the basis of their structures and substrate specifities: collagenases, gelatinases, stromelysins, matrilysins, furin-activated secreted MMPs, transmebranetype MMPs, GPI (glycophosphatidyl inositol)-anchored MT-MMPs, type II transmembrane MMPs and other $\mathrm{MMPs}^{9-11}$.

MMPs are synthetized in the form of preproenzymes. They are usually secreted from the cell as inactive proenzymes (beside the membrane MMPs). A proenzyme molecule is organized into the 3 basic structural domains: N-terminal propeptide, catalytic domain, and the C-terminal part of the molecule (Fig. 1)(ref. $\left.{ }^{1}\right) . N$ terminal propeptide consists of approximately 80-90 amino acids containing cysteine residue which interacts with catalytic zinc via its side chain thiol group (so called cystein switch), and this ensures the enzymatic latency of the proenzyme. Elimination of a highly conserved sequence (...PRCGXPD...) presented in the propeptide causes activation of zymogene ${ }^{12,13}$. The catalytic domain (approximately 170 amino acids) consists of the zinc- 
binding motive HEXXHXXGXXH and anchored methionine, which forms a unique structure, called Met-turn. Incidentally, this very structure is typical for the other metzincins to which MMPs belong ${ }^{14}$. This domain consists of five-stranded $\beta$-sheet, three $\alpha$-helixes, and bridging loops. The catalytic domain consists of two zinc (II+) ions and 2-3 $\mathrm{Ca}^{2+}$ ions. One $\mathrm{Zn}^{2+}$ appears in the active site and participates directly in the catalytic processes, the second $\mathrm{Zn}^{2+}$ (structural) together with $\mathrm{Ca}^{2+}$ are approximately $12 \AA$ distant from $\mathrm{Zn}^{2+}$ in the catalytic site ${ }^{15}$.

The C-terminal domain shows structural similarity to proteins of the hemopexin family, including e.g. hemopexin, vitronectin or placental protein II (it has about 210 amino acid residues). An ellipsoidal disk shape with a four bladed $\beta$-propeller structure is typical for the $\mathrm{C}$ terminal domain structure. Each blade consists of 4 antiparallel $\beta$-strands and an $\alpha$-helix. The first and second blades are connected by a disulfide bond. The catalytic and C-terminal domains, as shown in collagenase-1, are covered as entities in crystal with a connecting flexible peptide linker or a hinge region, which is freely bound ${ }^{16}$. The length of this hinge is extremely variable: 16 residues in collagenases or by contrast, 65 residues in MMP-15. The function of the linker, which contains a lot of prolines and connects catalytic and hemopexin-like domains, is not completely known.

The hemopexin-like domain (Fig. 1), essential to collagenases, breaks down the interstitial collagen triplehelix, allowing the catalytic domain to manifest its

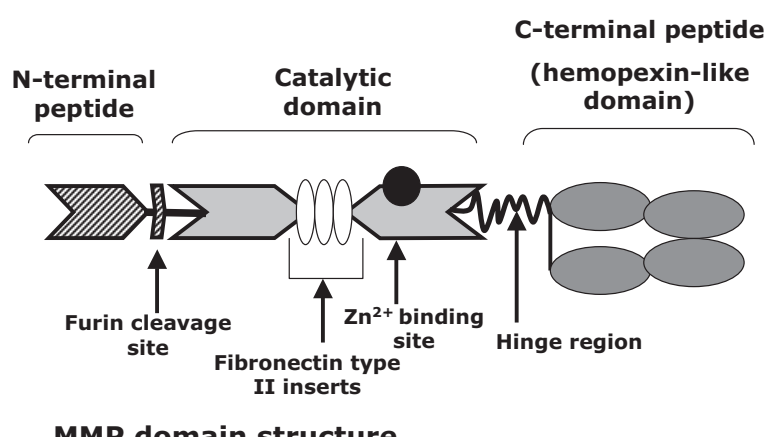

MMP domain structure

MMP group
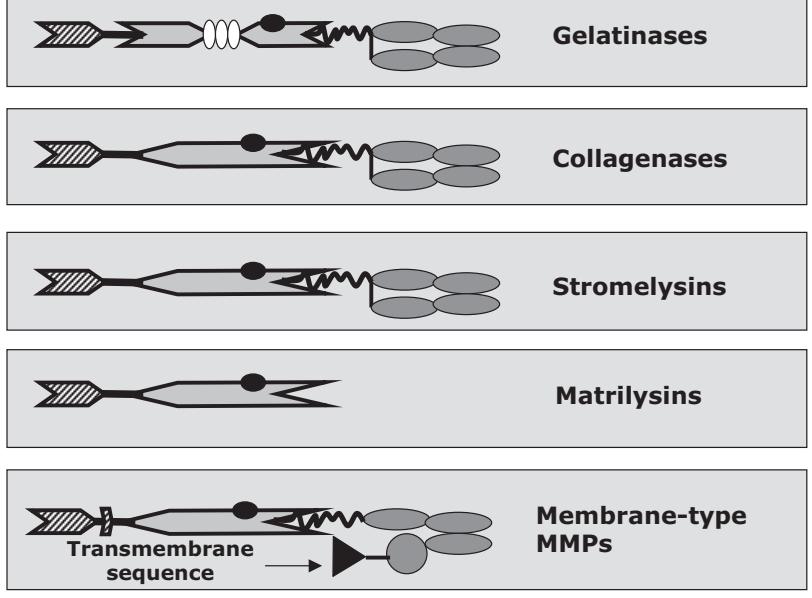

Fig. 1. MMP Domain Structure proteolytic activity on other substrates ${ }^{17}$. By contrast, matrilysins do not have this domain. There is an additional transmembrane domain in the membrane-type matrix metalloproteinases (MT-MMPs) that binds (anchors) the enzyme to the cell surface. This domain consists of a hydrophobic chain containing approximately 25 amino acids with a recognizing motive RXKR for the furin-like convertases at the end of the propeptide chain (with the exception of MT4-MMP and MT6-MMP). MT4-MMP and MT6-MMP are tethered to the cell surface via a glycosylphosphatidylinositol (GPI) memrane anchor ${ }^{1,18-20}$. Gelatinases consist of a domain having structural similarity to the matrix proteins. Three tandems of replicas of domain (58 amino acids) with the sequence fibronectin type II - like module of collagen bonding domain are found in all gelatinases, while a collagen type V - like module occurs only in longer gelatinases ${ }^{21}$.

On the other hand, matrilysins (MMP-7. MMP-26) have no hemopexin-like domain, making them the smallest MMP molecules. MMP-23 contains, in addition to the structure of matrilysins, a hydrophobic signal N-terminal anchor and cystein array ${ }^{22,23}$. MMP-19, MMP-20, MMP27 and MMP-12 can be classified as a new MMP group because it has no of the significant structural features of existing groups ${ }^{24-27}$. Some other MMPs contain a recognizing motive for the protein convertase RXRXKR, e.g. MT-MMPs and stromelysine- 3 in their molecules ${ }^{28}$.

\section{MECHANISM OF EFFECT AND SUBSTRATE SPECIFICITY OF MMPS}

Most of MMPs are able to degrade both majority and minority components of extracellular matrix; therefore, a lot of MMPs have wide substrate specificity. MMP-11 and MMP-23, whose ability to cleave the components of ECM is very low, are remarkable exceptions. This, however, does not exclude their ability to cleave other molecules (e.g. MMP-11 cleaves serpin) ${ }^{29,30}$. MMPs also cleave or activate molecules which are not components of ECM (e.g. MMP-2,3,7 cleave decorin that is an important reservoir of TGF- $\beta_{1}$. Cleavage of decorin initiates a release of the growth factor into the tissue which activates processes which are not necessarily directly connected with the extracellular matrix ${ }^{31}$.

\section{Collagenases}

Collagenases, compared to other MMPs, break down the native helix of collagen without previous denaturation of the molecule at neutral $\mathrm{pH}$ and include MMP-1, $-8,-13$ (see Tab. 1). They break down the $\alpha$ chain of the interstitial collagen (types I, II, III) into 2 specific parts, $1 / 4$ and 3/4 fragments, in the site of the molecule that has a relaxed triplehelix and which contains a more hydrophobic group. There is a sequence $\mathrm{Gly}^{775} / \mathrm{Ile}^{776}$ in the $\alpha_{1}$ chain of collagen type I, and Gly ${ }^{775} / \mathrm{Leu}^{776}$ in $\alpha_{2}$ chain of collagen type $\mathrm{I}^{32,33}$. Enzymes of this group markedly differ in their substrate specificity, e.g. neutrofil collagenase (MMP-8) 
prefers type I, while interstitial collagenase (MMP-1) collagen, type III. MMP-3 binds collagen type I, but it does not break down its triplehelix ${ }^{34-36}$. MMP-13 breaks down collagen type I and III, but slower than type $\mathrm{II}^{37}$.

Collagenases exhibit 2 different activities - catalytic and substrate binding ${ }^{37}$. De Souza and others suggest that the interstitial collagenases „hinge-domain“, rich in proline, simulates the collagen-like conformation ${ }^{38}$. With this domain, the enzyme is able to destroy the quaternary structure of the collagen triplehelix. Both similar structures of collagen and collagenase interact together forming a so called proline zipper. This destabilizing step leads to the following cleavage. The catalytic domain then breaks down only one fiber of collagen triplehelix in the relaxed structure. After this cleavage other MMPs can also participate in the following cleavage. The hemopexin-like domain also plays a certain role in stabilizing indirectly the procollagen-like domain of collagenase. Another possibility is that this domain ensures a nonfunctional bond of the substrate and then the "hinge-domain" ensures correct orientation of the substrate before its cleavage ${ }^{39}$. Membrane-type MMPs manifest approximately the same substrate specificity as analogous free MMPs. Collagen is not only the substrate for MT-MMPs. They also differ in activity (e.g. MMP-14 is 5-7 times less effective in cleavage of type I hydrolyzed collagen than analogous MMP-1 but in contrast manifests an 8 times higher gelatinolytic activity than MMP-1 ${ }^{40}$ ). MT4-MMP breaks down gelatin and synthetic substrates but it is intact to collagen type I and IV, fibronectin or laminin ${ }^{41}$. Others are able to break down proMMPs and thus activate them (in detail see the MMPs activation and inhibition).

\section{Gelatinases}

This category includes MMP-2 and MMP-9 (see Table 1). In particular gelatinases break down denatured collagen, type IV intact collagen of basal membranes and also non-denatured collagens type V, VII, X, XIV, fibronectin, agrecan, and elastin. MMP-2 is even considered to break down type I native collagen ${ }^{34}$. Further studies showed that it only binds intact collagen to prevent its autolytic inactivation ${ }^{42}$. Besides gelatin and other forms of denatured collagen, MMP-9 breaks down a whole range of other physiological substrates ${ }^{43,44}$. Although the cleaved sequences are not yet fully identified, the main one which was cleaved by a majority of MMPs (not only MMP-9), contains a Pro-X-X-Hy-(Ser/Thr) motive where $\mathrm{X}$ is any amino acid residue and $\mathrm{Hy}$ is hydrophobic amino acid residue in position $\mathrm{P}_{3}$ to $\mathrm{P}_{2}$. Another group contained Gly-Leu-(Lys/Arg) motive in a position between $\mathrm{P}_{1}$ and $\mathrm{P}_{2}$. The last group of substrates contained arginine residues both in $\mathrm{P}_{1}$ and $\mathrm{P}_{2}$ and these substrates were explicitly preferred by MMP-9(ref. $\left.{ }^{45}\right)$.

\section{Stromelysins}

The substrate specificity of stromelysins is relatively wide. They break down all non-collagen ECM proteins (proteoglycans, glycoproteins, fibronectin, and laminin). Type IV collagen is cleaved by stromelysins only in globu- lar but not in helical conformation. Stromelysines include MMP-3, MMP-10, MMP-11 (see Table 1).

\section{Macrophagous elastase and other MMPS}

This category includes MMPs with the ability to break down other molecules. Macrophagous elastase (MMP-12) shares its ability to break down elastin with only a few MMPs (gelatinases and matrilysins) and is also able to break down fibronectin, laminin, basal membrane collagen, entactin, chondrotin sulfate and others ${ }^{46}$. This enables macrophages to penetrate basal membranes and thus subsequently remodel the tissue affected by inflammation. However, basal membranes are also degraded by MMP$19^{27}$. Components of enamel (mainly majority emalogenin) are specifically degraded by MMP-20(ref. ${ }^{47}$ ). Many MMPs (MMP-3, MMP-13 and MMP-8, MT1-MMP) break down in vitro IGD agrecan bond in the position $\mathrm{Asn}^{341}$ $\mathrm{Phe}^{342}$ (ref. ${ }^{15}$ ).

\section{MATRIX METALLOPROTEINASES ACTIVATION AND INHIBITION}

Regulation of MMPs activity is a complex process. It includes various levels of activation of latent MMPs, inhibition, secretion of the enzyme molecule and the regulation of gene transcription or inhibition of MMPs activity by tissue inhibitors of metalloproteinases (TIMPs). The selective expression of genes for tissue-specific MMPs and their inducibility by biologically active molecules (growth factors, cytokines, oncogenes, tumor promoters) are presently being studied.

\section{a) Regulation of MMPs gene expression}

Most genes for MMPs are inducible; besides biologically active molecules, genes can be induced by various chemical agents such as phorbol esters ${ }^{48}$. Gene expression can be inhibited by some suppressive factors (TGF- $\beta$, glucocorticoids, retinoic acid)(ref. $\left.{ }^{49,50}\right)$. Genes for MMPs are expressed only if the tissue, whether under physiological or pathological conditions, is remodeled. MMP-2 is an exception; regulation is realized at the level of activation and inhibition of enzyme activity ${ }^{51,52}$. Promoters for most MMP genes include the same AP-1 element in position - 70 and one or two replicas of PEA-3 element in position between -140 and -200 . The first one reacts with Fos and Jun proto-oncogene family. PEA-3 element reacts with Ets family of transcription factors. Mutation analyses showed that the AP-1 sequence itself or in combination with PEA3 regulate the basic stages and inducibility of these genes by means of various molecules. Transcription factors which recognize these sites are the already mentioned proto-oncogenes in the cis conformation (cis-elements). For example, stromelysin-1 PDGF responsive element (SPRE). One of these transcription factors, recognizes the site -1573 on the gene for MMP-3, but it has also been identified on other promoters of MMP genes; therefore it generally results in regulation of MMP gene expression ${ }^{20}$. Natural sequence variations of MMP genes promoters can 
Table 1. Classification of Matrix Metalloproteinases

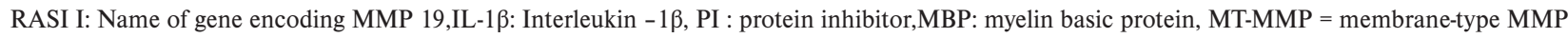

\begin{tabular}{|c|c|c|c|c|c|}
\hline MMP & Alternative Names & Group & EC Number & Chromosome & Substrates \\
\hline MMP-1 & $\begin{array}{l}\text { Collagenase } \\
\text { (Type I, interstitial) }\end{array}$ & Collagenases & EC 3.4.24.7 & $11 \mathrm{q} 22-\mathrm{q} 23$ & $\begin{array}{l}\text { Collagens (I,II,III,VIII a X); gelatin; aggrecan; } \\
\text { L-selectin; IL-1 } \beta \text { proteoglycans, entactin; } \\
\text { ovostatin; MMP-2; MMP-9 }\end{array}$ \\
\hline MMP-2 & $\begin{array}{l}\text { Gelatinase A } 72 \mathrm{kDa} \\
\text { Gelatinase Type IV } \\
\text { Collagenase }\end{array}$ & Gelatinases & EC 3.4.24.24 & $16 q 13$ & $\begin{array}{l}\text { Collagens (I,IV,V,VII,X,XI a XIV);gelatin; } \\
\text { elastin;fibronectin;aggrecan; MBP; osteo- } \\
\text { nectin; laminin-1; MMP-1; MMP-9; MMP-13 }\end{array}$ \\
\hline MMP-3 & $\begin{array}{l}\text { Stromelysin-1 } \\
\text { Proteoglycanase }\end{array}$ & Stromelysins & EC3.4.24.17 & $11 \mathrm{q} 23$ & $\begin{array}{l}\text { Collagens (III,IV.V, a IX); gelatin; aggrecan; } \\
\text { perlecan; decorin; laminin; elastin; casein; } \\
\text { osteonectin; ovostatin; antactin; plasminogen; } \\
\text { MBP; IL-1 } \beta \text {; MMP-2/TIMP-2; MMP-7; MMP- } \\
\text { 8; MMP-9; MMP-13 }\end{array}$ \\
\hline MMP-7 & $\begin{array}{l}\text { Matrilysin } \\
\text { Putative MMP }\end{array}$ & Matrilysins & EC 3.4.24.23 & 11q21-q22 & $\begin{array}{l}\text { Collagens (IV a X); gelatin; aggrecan; decorin; } \\
\text { fibronectin; laminin; entactin; elastin; casein; } \\
\text { transferrin; plasminogen; MBP; } \beta 4 \text {-integrin; } \\
\text { MMP-1; MMP-2; MMP-9; MMP-9/TIMP-1 }\end{array}$ \\
\hline MMP-8 & $\begin{array}{l}\text { Neutrophil } \\
\text { collagenase }\end{array}$ & Collagenases & EC 3.4.24.34 & 11q21-q22 & $\begin{array}{l}\text { Collagens (I,II,III,V,VII,VIII a X); gelatin; } \\
\text { aggrecan; fibronectin }\end{array}$ \\
\hline MMP-9 & Gelatinase B & Gelatinases & EC3.4.24.35 & 20q11.2-q13.1 & $\begin{array}{l}\text { Collagens (IV,V,VII,X a XIV); gelatin; entac- } \\
\text { tin; aggrecan; elastin; fibronectin; osteonectin; } \\
\text { plasminogen; MBP; IL-1 } \beta\end{array}$ \\
\hline MMP-10 & Stromelysin-2 & Stromelysins & EC3.4.2.22 & $11 \mathrm{q} 22.3-\mathrm{q} 23$ & $\begin{array}{l}\text { Collagens ( III-V); gelatin; casein; aggrecan; } \\
\text { elastin; MMP-1; MMP-8 }\end{array}$ \\
\hline MMP-11 & Stromelysin-3 & Stromelysins & not assigned & $22 q 11.2$ & Unknown (casein) \\
\hline MMP-12 & $\begin{array}{l}\text { Macrophage metal- } \\
\text { loelastase }\end{array}$ & & EC 3.4.24.65 & $11 \mathrm{q} 22.2-\mathrm{q} 22.3$ & $\begin{array}{l}\text { Collagen IV; gelatin; elastin; casein; fibronec- } \\
\text { tin; vitronectin; laminin; entactin; MBP; } \\
\text { fibrinogen; fibrin; plasminogen }\end{array}$ \\
\hline MMP-13 & Collagenase-3 & Collagenases & not assigned & $11 \mathrm{q} 22.3$ & $\begin{array}{l}\text { Collagens (I,II,III,IV,IX,X,a XIV); gelatin; } \\
\text { plasminogen; aggrecan; perlecan; fibronectin; } \\
\text { osteonectin; MMP-9 }\end{array}$ \\
\hline MMP-14 & MT1-MMP & $\begin{array}{l}\text { Membrane } \\
\text { MMP }\end{array}$ & not assigned & 14q11-q12 & $\begin{array}{l}\text { Collagens (I-III); gelatin; casein; fibronectin; } \\
\text { laminin; vitronectin; entactin; proteoglycans; } \\
\text { MMP-2; MMP-13 }\end{array}$ \\
\hline MMP-15 & MT2-MMP & $\begin{array}{l}\text { Membrane } \\
\text { MMP }\end{array}$ & not assigned & $16 \mathrm{q} 12.2-\mathrm{q} 21$ & $\begin{array}{l}\text { Fibronectin; entactin; laminin; perlecan; } \\
\text { MMP-2 }\end{array}$ \\
\hline MMP-16 & MT3-MMP & $\begin{array}{l}\text { Membrane } \\
\text { MMP }\end{array}$ & not assigned & $8 \mathrm{q} 21$ & $\begin{array}{l}\text { Collagen III; gelatin; casein; fibronectin; } \\
\text { MMP-2 }\end{array}$ \\
\hline MMP-17 & MT4-MMP & $\begin{array}{l}\text { Membrane } \\
\text { MMP }\end{array}$ & not assigned & $12 \mathrm{q} 24$ & Unknown \\
\hline MMP-18 & Collagenase- 4 & Collagenases & not assignated & Unknown & Unknown \\
\hline MMP-19 & RASI-1 & & not assigned & $12 q 14$ & Gelatin; aggrecan; fibronectin \\
\hline MMP-20 & Enamelysin & & not assigned & $11 \mathrm{q} 22$ & Amelogenin; aggrecan \\
\hline MMP-21 & & & not assigned & $1 \mathrm{p} 36.3$ & Unknown \\
\hline MMP-22 & & & not assigned & $1 \mathrm{p} 36.3$ & Unknown \\
\hline MMP-23 & & & not assigned & $11 \mathrm{q} 22$ & Amelogenin \\
\hline MMP-24 & MT5-MMP & $\begin{array}{l}\text { Membrane } \\
\text { MMP }\end{array}$ & not assigned & $20 \mathrm{q} 11.2$ & Pro-MMP 2 \\
\hline MMP-25 & $\begin{array}{l}\text { Leukolysin/MT6- } \\
\text { MMP }\end{array}$ & $\begin{array}{l}\text { Membrane } \\
\text { MMP }\end{array}$ & not assigned & $16 \mathrm{p} / 3.3$ & $\begin{array}{l}\text { Pro-gelatinase A; fibrin; fibronectin; collagen } \\
\text { IV; gelatin }\end{array}$ \\
\hline MMP-26 & $\begin{array}{l}\text { Endometase, } \\
\text { matrilysin-2 }\end{array}$ & Matrilysins & not assigned & Unknown & $\begin{array}{l}\text { Gelatin I } \alpha \text {; P1; fibrinogen; fibronectin; } \\
\text { vitronectin; } \beta \text {-casein }\end{array}$ \\
\hline MMP-27 & & & not assigned & Unknown & Unknown \\
\hline MMP-28 & Epilysin & & not assigned & $17 \mathrm{q} 11.2$ & Casein \\
\hline
\end{tabular}


modify MMP gene expression in many organisms and in a variety of ways.

There are a number of described signaling pathways resulting in the MMPs expression. Inflammatory cytokines, TNF- $\alpha$ and IL- 1 trigger ceramide signaling. Ceramide-dependent expression of MMP-1 in human dermal fibroblast is influenced by the three distinct MAP kinase pathways, ERK1/2, stress-activated protein kinase (SAPK)/JNK and p38(ref. $\left.{ }^{53,54}\right)$. One inducible factor is also ultraviolet B irradiation, which increases expression of MMP-1, MMP-3 and MMP-9 in human dermal fibroblasts. Protein kinases JNK-2 are activated by stress via reactive free radicals and via lipid peroxidation ${ }^{55,56}$.

Gene expression is influenced also by the ECM-cell and cell-cell interactions. As an example, we can also mention glycoprotein EMMPRIN (extracellular matrix metalloprotinase inducer) that was first identified on the surface of human tumor cells. It stimulates MMP-1,-2 and -3 production in human fibroblasts and increases mRNA MMP-1 expression; this stimulating effect requires activity of $\mathrm{p} 38^{57,58}$. MMPs or EMMPRIN synthesis can also be influenced by the changed hemodynamic overload ${ }^{59}$. MMP-9 is induced by $\alpha_{5} \beta_{1}$ integrin-fibronectin interaction during the differentiation of macrophages ${ }^{60}$. MT1MMP expression is triggered by the cells of endothelium, fibroblasts and also neoplastic cells via interaction by $\alpha_{2} \beta_{1}$ integrin $^{61}$.

\section{b) Regulation of MMPs enzyme activity by cystein switch mechanism}

MMPs are expressed as zymogens. There is a certain reserve of inactive MMP bonded to various components of ECM in the extracellular space. Certain stimuli lead to fast MMPs activation. MMP-2 binds to the ECM structures containing elastin, MMP-3 to basal membranes and occasionally to collagen fibrils and MMP-13 to proteoglycans, collagen and elastin ${ }^{62}$. Not all MMPs are stored in latent forms. MMP-8 is in specific granules, MMP-1 and MMP-3 are constitutively produced after the release of cytokines and inflammatory mediators ${ }^{1}$.

After propeptide cleavage, the MMP zymogens are changed into active enzymes. Propeptide contains a conservative sequence PRG[V/N]PD, which maintains the enzyme in latent form by the chelating action of cystein residuum to $\mathrm{Zn}^{2+}$ ions at the catalytic site of the enzyme. PRCG[V/N]PD motive is usually found in propeptides of matrixins, but - $\mathrm{SH}$ group of this sequence are only found in native propeptides. ProMMPs do not react easily with -SH reactants until $\mathrm{Zn}^{2+}$ in proMMPs is eliminated by some chelating molecules ${ }^{13,63}$. SH cystein group in PRCG[V/N]PD interacts with $\mathrm{Zn}^{2+}$ in enzymatic active sites. This interaction $\left[\mathrm{Zn}^{2+}\right.$-cystein] maintains zymogene inactivity. Activation of the enzyme is explained by a so called mechanism of a cystein switch ${ }^{64,13}$. The key step is dissociation of zinc-cystein interaction. Then zinc interacts with water. Extracellular activation of the enzyme includes 2 steps. The first is initial cleavage of the MMP propeptide by protease, destabilization of propeptide binding interactions, and break of coordination bond of cystein and $\mathrm{Zn}^{2+}$ ions. The second step is the final cleavage of the propeptide, that is usually ensured by another MMP. The result is a matured enzyme. In many cases, MMPs cannot participate in reaction until the last part of the propeptide is removed. In MT-MMPs and stromelysine- 3 the active site is formed directly after the previous interaction of 11 residues containing consensus RXKR (where X can be any amino acid) with the furine family of enzymes - with endopeptidases associated with the Golgi apparatus. Intracellular cleavage of MT-MMPs and stromelysine-3 by the furine-like enzyme activates the enzyme ${ }^{65-67}$.

There are also alternative ways of MMPs activation. MT1-MMP is as an inactive zymogene located on the cell membranes. Gelatinase A (MMP-2) and collagenase-3 can be activated extracellularly on the surface of cells by the active, membrane bound MMP which, in this case, plays the role of enzyme and also membrane receptor. This activation process requires active MT-1-MMP and TIMP-2 bond to MT-1-MMP(ref. $\left.{ }^{68-70}\right)$.

\section{c) Inhibition of MMPs by means of TIMPs}

Tissue inhibitors of matrix metalloproteinases (TIMPs) are the main endogenous regulators of MMPs in the tissue. They are proteins of size 21-30 kDa. Four homologous molecules termed TIMP-1,-2,-3,-4 have been described. They bind to MMPs in a ratio $1: 1$ forming binary noncovalent complexes with very high $\mathrm{K}_{d}\left(10^{-9}-10^{-10}\right)$. In this way they protect binding sites for the substrates being split off $^{71}$. TIMP-1 forms the complex preferentially with MMP9, and TIMP-2 preferentially with MMP-2. The crystalline structure of the complex formed between TIMP-1 and catalytic domain MMP-3 has already been described: critical sites of the whole inhibition process are localized around a disulfide bond between $\mathrm{Cys}^{1}$ and $\mathrm{Cys}^{70}\left(\right.$ ref. $\left.^{72}\right)$. The Nterminal $\alpha$-amino and carbonyl groups of $\mathrm{Cys}^{1}$ bidentately coordinate the $\mathrm{Zn}^{2+}$. Thus TIMPs prevent autocatalytic cleavage of the MMP molecule leading to the formation of the active molecule (mechanism of cystein switch). Active membrane bound MMPs can be inhibited with TIMPs in complexes with other molecules. A catalytic amount of MMP-3 considerably activate proMMP-9 in the absence of TIMP-1, but not the [proMMP-9-TIMP-1] complex. Thus MMP-3 is inhibited by TIMP-1(ref. ${ }^{73,74}$ ). If the ternary complex [proMMP-9-TIMP-1-MMP-3] is formed, interaction between proMMP-9 and TIMP-1 weakens and partially dissociates into free proMMP-9 and [TIMP-1-MMP-3] complex. Thus, a higher concentration of MMP-3 is needed for the activation of proMMP-9, which is inhibited by TIMP-1, which must be saturated by another matrixin ${ }^{75}$. This explains what impairs MMPs inhibition mediated by TIMPs. TIMP-1 expression is regulated by cytokines (TNF- $\alpha$ ) which can modify TIMP-1 expression via induction of nuclear transcription factors, TIMP-2 expression by cytokine stimulation does not take place $^{76,77}$.

TIMP-3 has been identified in the myocardium of the mouse embryo, where it probably takes part in ECM embryonal remodeling and heart development ${ }^{78}$. It differs from other TIMPs by direct binding to the ECM compo- 
nents (TIMP-1 and TIMP-2 are freely diffusible in the interstitial space). Therefore, TIMP-3 models MMP activity better than other TIMPs $\left(\right.$ ref. $\left.^{79}\right)$. TIMP-4 has been detected in low concentrations in kidneys and the colon. It is not in lungs, liver or the brain. By contrast, high TIMP-4 expression has been identified in the heart ${ }^{80}$. TIMPs also show other biological functions. TIMP-1 and TIMP-2 have mitogenic activity in various cell types, TIMP- 2 influences interaction/adhesion between substrates and the cell ${ }^{81,82}$. TIMPs overproduction slows down the growth of tumor cells. Decrease in TIMPs concentration during the healing of damaged tissue increases collagenolytic activity. Reduced TIMPs activity also enables tumor cells to impair the surrounding extracellular matrix, and thus they migrate to the adjacent tissues. Therefore it is clear that regulation of the balance between collagenases and their inhibitors is necessary for remodeling of tissue whose impairment can significantly change the tissue functional characteristics $^{83}$.

\section{MMPS AND CARDIAC TISSUE}

\section{Structure and Function of Myocardial ECM}

Cardiac tissue consists of the two basic components - cellular and extracellular. Two thirds of the total tissue content comprises myocytes, one third of cellular matrix is occupied by other cells - fibroblasts, endothelial cells, other cells and acellular components - extracellular tissue fluid and extracellular matrix. Pathological changes at the molecular level are characterized by the change in the qualitative and quantitative constitution of ECM and the constitution of myocytes. These changes are the result of tissue remodeling, as well as the changed synthesis, degradation, maturation and incorporation of individual ECM components that form a highly organized structure with not only structural but also regulating and communicative functions ${ }^{84,85}$. Slow turnover of extracellular matrix is characteristic of healthy cardiac tissue: synthesis and degradation are in a dynamic balance. The structural backbone myocardial ECM is formed by a fibrillar collagenous network consisting, above all, of collagen type I and III that are extremely resistant to proteolytic cleavage. However, myocardial ECM also contains components in lower quantity, which connect individual components, communicate with myocytes, modulate transport and organization of ECM or individual components, influencing cellular signaling. Besides various minor collagens (type IV, V, VI, VII, VIII, IX, X, XV, XVIII and others)(ref. ${ }^{86,87}$ ) there is a whole range of glycoproteins, glycosaminglycans (heparan sulfate and chondroitin sulfate), microfibrilar proteins (fibrilin and fibulin), laminin, fibronectin, elastin, integrins, tenascins and others ${ }^{88-90}$. There are also various groups of enzymes which take part in degradation of ECM components in myocardium, such as the above discussed MMPs and ADAM metalloproteinasses, seryleproteases (plasmin, neutrophil elastase, cathepsin G), cysteine proteases (cathepsin B,L and S), aspartyl proteases (cathepsin D)(ref. $\left.{ }^{91}\right)$.

\section{MMPS AND DISEASE OF MYOCARDIUM}

Myocardial remodeling in various pathological situations is characterized by several different processes of cardiac tissue turnover. The first, which is characteristic of myocardial infarct, is very similar to the process of any damaged tissue healing. The previous ischemic injury of the original tissue, is followed by a repair processes which removes necrotic tissue and replaces it with a new one. The second is a result of long-term reaction of cardiac tissue under volume- or pressure-overload. Thus, tissue turnover enables the maintenance of heart function even at changed pressure and volume conditions and leads to right-ventricular or left-ventricular heart failure. This is a qualitative and quantitative change of ECM components.

\section{MMPS Function in Ischemic Cardiac Tissue}

An acute ischemic phase (proteolytic and redox insult) activates MMPs and this results in the impairment of the ECM at the site of the ischemic injury; TIMP concentration is also changed. Later on, concentrations of MMP inhibitors are lowered, hence degradation of ECM components continues. This leads to dilatation and systolic failure. Continuous ECM synthesis at sites distal from infarcted area leads to fibrosis and diastolic failure. Structural remodeling of tissue after the myocardial infarct leads to development of hypertrophy and tissue stretching. These processed are then accompanied by development of fibrosis in the non-infarcted part of the heart and dilatation of the infarcted part. This together results in cardiac failure ${ }^{92,93}$.

After a myocardial infarct, MMP-1 in cardiac tissue is activated by the proteinases of inflammatory cells and at the same time considerable reduction in number of present TIMPs occurs ${ }^{94,95}$. In ischemic left ventricle in rats, increased collagenolytic activity was found 2 days after coronary artery ligation, a maximum was reached after 7 days, and then a decrease in MMP-1 activity and a parallel increase in MMP-2 and MMP-9 activities were observed. An increase in mRNA MMP-1 expression was not detected earlier than 7 days after coronary artery ligation. TIMP mRNA transcription is already observed after 6 hours, a maximum is reached after 2 days of infarct. Post-translational activation of latent MMP-1 is, in the process of injured myocardial tissue healing, more important than transcription of appropriate mRNA proMMP-1. Transcription of MMP-1 occurs after depletion of latent enzyme amount. TIMP mRNA synthesis is regulated by activation of matrix metalloproteinases. Balance between collagenase activation and TIMP inhibition determines the stage of collagenolysis in infarcted tissue ${ }^{96}$. Hence, MMP-1 is not the enzyme which is fully responsible for collagen degradation in ischemic myocardium. Therefore, other enzymes from the group of cysteine proteases (e.g. plasmin) or lysosomal cysteine proteases (e.g. cathepsin $\mathrm{G})$ are at work here ${ }^{91}$. Delayed reperfusion changes activity of MMPs in the infarcted focus of the rat's heart, as well as the lowering of activities of MMP-1, MMP-2 
( $50 \%$ to $60 \%$ after 7 days) and MMP-9 (up to $84 \%$ after 48 hours $)^{97}$. On the other hand, in early reperfusion, by means of initiated inflammatory processes, the secretion of active MMP-9 part by infiltrating neutrophils, probably activates proteasis of other MMPs and the mechanism of the infarcted focus turnover process is different. By contrast, inhibition of the inflammatory process is associated with an increased risk of ventricular aneurysms, cardiac ruptures and death ${ }^{98}$. MMP-2 release during reperfusion after ischemia contributes to the cardiac mechanical dysfunction. Specific inhibition of MMPs may be a new strategy in the treatment of ischemia-reperfusion injury ${ }^{99}$. For example, an early left ventricle hypertrophy was avoided by administration of broad spectrum MMP inhibitor (CP$471,474)$ to mice with experimentally induced myocardial infarct ${ }^{100}$.

\section{MMPs Function in Remodeling of Hypertrophic Cardiac Tissue}

Pressure or volume overload of heart muscle leads to hypertrophy and consequent cardiac tissue remodeling.

In spontaneously hypertensive rats, the increase in MMPs activity (e.g. MMP-2, 9) appears during heart failure. TGF- $\beta$ is a known inducer of collagens and TIMPs expression and inhibitor of MMPs (activity or expression). In spite of this, profibrotic components are increased during hypertrophic remodeling which leads to development of cardiovascular fibrosis and diastolic dysfunction ${ }^{92}$. In experimentally induced myocardial fibrosis in hypertensive rats, the increase in MMP-2 activity was detected after 2 months, while activity for MMP-1 remained unchanged ${ }^{101}$.

Some studies also showed that the total MMPs activity in patients in the last stages of cardiomyopathies was increased ${ }^{102,103}$. There is considerable selective reduction of tissue MMP inhibitor expression and independent increase in gelatinolytic activity presented by MMP-9 activity in the failing human heart ${ }^{102}$. In some hypertrophic cardiomyopathies, increase in tissue inhibitor concentration was detected, compared to controls, up to 100 times higher ${ }^{104}$, showing the exceptional position of TIMPs in the process of tissue remodeling.

We demonstrated increased expression of TIMP-1 mRNA (more than 3.5 times) and at the same time a 2.5 times increase in MMP-2 expression in hypertrophied right ventricle after the 14 days of hypoxic hypoxia $\left(10 \% \mathrm{O}_{2}\right)$ in rats $^{105}$. By contrast, the decrease in TIMP-1 and MMP-2 expression occurred after a 4-day hypoxic stimulus ${ }^{106}$.

\section{MMPs and Dilated Cardiomyopathy}

In dilated cardiomyopathies (DCM), ventricular wall weakening occurs, myocytes are hypertrophied and disruptions in ECM appear. The DCM result is systolic heart failure. It was demonstrated in hamster DCM models that MMPs activity was increased after 180 days and did not change within 310 days. This increased MMPs activity was associated with reduction in TIMPs expression $^{107}$. Similarly in humans, MMP-1 is specifically and differentially induced, while TIMS expression is re- duced (inhibited)(ref. $\left.{ }^{107}\right)$. There are two possible explanations: it is either mutation, affecting the propeptide part of MMP-1, which leads to production of already active MMP-1 without the need for posttranslational activation or a dramatic reduction in the presence of MMP tissue inhibitors $^{104}$. Beside MMP-1, MMP-3 and MMP-9 activities are also increased. Increased MMP-3 activity was detected during left ventrical dilatation in animals and humans ${ }^{108,103}$. Pigs with congestive heart failure had MMP-1 activity higher by up to $319 \%$ in the left ventricle, MMP-2 activity increased by $194 \%$ and MMP-3 by $493 \%$ in comparison with healthy animals ${ }^{109}$. The reduction of cross-links between collagenous fibrils also occurs during dilatation. Newly formed collagen is not connected by cross-links; collagenous depositions are made and they succumb to the increased turnover as a result of increased MMPs activity in the process of cardiac tissue dilatation. An interesting finding was that higher activity of neutrophil collagenase (MMP-8) was detected in human cardiac tissue at $\mathrm{DCM}^{110}$. In rats with symptomatic congestive heart failure, significant increase in MMPs activity occurr.. Some authors further showed that ventricular dilatation can develop even when synthesis of collagen considerably exceeds its degradation. It is clear that the concentration of the total collagen is not responsible for the process of ventricular compliance. However, decreased interation between collagen and integrin receptors, changes in collagen cross-linking or inner changes in architecture of cardiomyocytes play important roles in ventricular remodeling ${ }^{111}$.

\section{SYNTHETIC INHIBITORS OF MMPS}

Several chemotherapeutic agents, antibiotics and synthetic peptides modulated production or activity of different classes of MMPs, and were tested with varying success in animals and patients above all those with malignant diseases. Disruption of tissue organization is a hallmark of malignant growth, it creates space for local tumor invasion and allows the tumor cells to gain access to the vascular and lymphatic systems. Lately, great effort has been focused on the development of effective specific inhibitors of MMPs and their use in therapy of non-malignant diseases ${ }^{8}$. MMPs inhibitors can be divided into 4 groups: a) peptidomimetic inhibitors of MMPs, b) non-peptidomimetic inhibitors of MMPs, c) tetracycline derivates, d) biphosphonates. The structures of some of these are showen in Fig. 2.

\section{a) Peptidomimetic Inhibitors of MMPS}

The first synthetic inhibitors of MMPs (peptidomimetic) were developed on the basis of our knowledge of the sequence of sites where collagenous molecules are cleaved by MMP-1. These inhibitors contain a chelating group which binds zinc in the MMP active site. BB-94 (Batimastat)(ref. ${ }^{112}$ ) and this inhibits the right side of the cleavage site is a typical example of such inhibitor. Inhibitors based on the sequence of the left side of the 


\section{Peptidomimetic inhibitors}

BB-94<smiles>CCC[C@H](C(=O)N[C@@H](Cc1ccccc1)C(N)=O)[C@H](CSc1cccs1)C(=O)NO</smiles>

SE205<smiles>CNC(=O)C(Cc1ccc(OCCC[C@H](C(=O)NO)[C@@H](CC(C)C)C(=O)NO)cc1)C(=O)NC</smiles>

Non-peptidomimetic inhibitors

AG3340

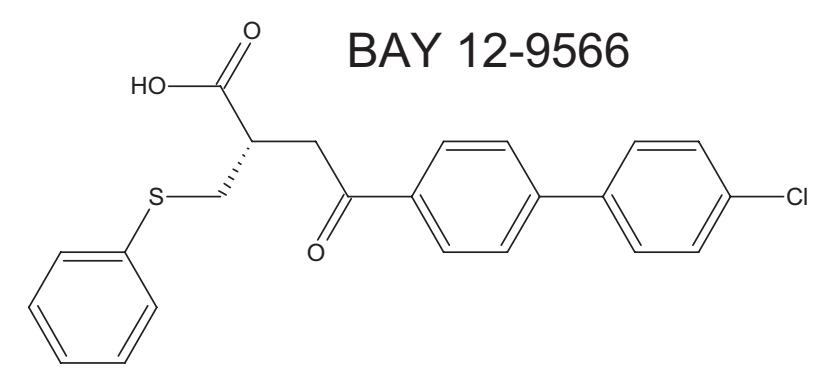

Bisphosphonates

VS-6<smiles>CN(C)c1c[n+](CC(P(=O)([O-])O)P(=O)(O)O)ccn1</smiles>

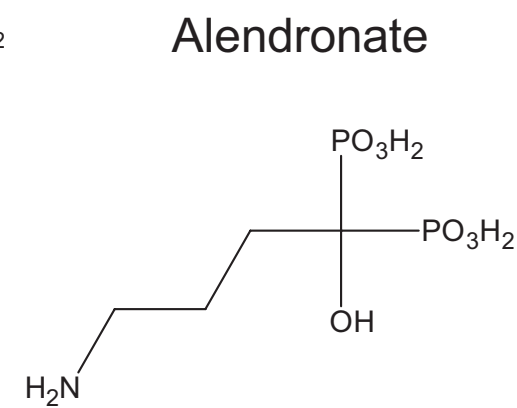

Fig. 2. Synthetic Inhibitors of MMPs.

MMP cleavage site were much weaker ${ }^{113}$. To maintain the constant structure of these inhibitors, a so called hydroxamate structure was chosen. The hydroxamate serves as an effective ligand of $\mathrm{Zn}^{2+}$ ion in the MMP active site. Modification of the side chain of the hydroxamate (e.g. by the succinate) increases the inhibiting effect of these compounds. A group of these inhibitors (e.g. BB-94 or BB-1101) has broad substrate specificity. Further effort was made to develop a compound that would inhibit the right side as well as the left side of the cleavage site of the enzyme (e.g. SE205)( ref. $^{114}$ ).

Peptidomimetic inhibitors have been successfully used in experimental cardiology. For example, administration of Batimastat prevented heart failure which would have been caused by myocardial hypertrophy development or by diastolic dysfunctions in young transgenic mice with enhanced expression of TNF- $\alpha$ (restricted to myocardium)(ref. ${ }^{115}$ ). 


\section{b) Non-Peptidomimetic Inhibitors of MMP}

The group of nonpeptidic (non-peptidomimetic) inhibitors with broad spectrum of inhibtion include, for example, $\mathrm{N}$-sulfonyl amino acid hydroxymates that have been orally-available such as CGS27023A and AG3340. Newly developed arylhydroxymate compounds are still being tested for their contingent mutagenic effects. Other non-hydroxymate alternatives of synthetic inhibitors include carboxylic acids and thiols that are able to bind to zinc in the catalytic center of MMP(ref. ${ }^{116}$ ). BAY 129566 as an example of such an inhibitor is a biphenyl derivate of the anti-inflammatory drug Fenbufen ${ }^{117}$. From carboxylates, inhibitor PD166793 has been successfully used in experimental studies. Administration of this inhibitor to pigs with congestive heart failure helped to diminish dilatation and remodeling of the left ventricle ${ }^{118}$. The same inhibitor prevented the loss of heart mechanical function caused by peroxynitrite ${ }^{119}$. Failing heart in spontaneously hypertensive rats treated by PD166793 had reduced volume of the left ventricle compared to untreated animals where the value of peak $+\mathrm{dP} / \mathrm{dt}$ was comparable with control animals ${ }^{120}$. In case of rats with spontaneous hypertension, activity of inhibitors reduced left-ventricle dilatation, maintained systolic function, normalized MMP/TIMP expression and reduced the volume of collagenous fraction ${ }^{121}$. Thiol groups, due to their ability to bind zinc at the active site, are incorporated into the molecules of MMPs inhibitors. In spite of the fact that the real afinity of "monodentate“ thiol groups is less than „bidentate" carboxylates and hydoxamates, easier solubility and ionization balance their final inhibiting potential ${ }^{122}$.

\section{c) Derivatives of Tetracyclines}

Some agents of the group of antibiotics - derivatives of tetracyclines (doxycycline, minocycline and chemically modified tetracyclines (CMT)) are inhibitors of MMPs. These agents inhibit not only activity but also production of MMPs. The inhibiting effect is ensured by both blocking the activity of the enzyme by chelated zinc at the bond site and interference with proteolytic activation of proMMPs; MMPs expression is also reduced ${ }^{123,124}$. CMT-3 (metastat), which is not toxic and has a long half-life is especially effective ${ }^{122}$.

\section{d) Biphosphonates}

Biphosphonates are synthetic analogues of pyrophosphate with high affinity for hydroxypatite crystals of bone tissue; they prevent bone re-adsorption. They are successfully used for the treatment of osteoporosis and other bone diseases. However, in the treatment of cardiovascular diseases they have not been used yet. Mechanisms of MMP activity have not been sufficiently investigated. It has been suggested that their ability to induce production of cytokines results in MMP inhibition ${ }^{125-127}$.

\section{CONCLUSION AND FUTURE PROSPECTS}

This review summarizes some of the recent discoveries that have shed new light on the role of MMPs in remodeling of cardiac tissue. In the past, the role of the extracellular matrix of myocardium was considered to be passive. Development of a whole range of analytic and biochemical approaches has significantly contributed to the clarification of the structure and function of this compartment of heart muscle. Matrix metalloproteinases take part in degradation of extracellular matrix. In mature tissue they have the primary function of repair and protection, more so than in the process of morphogenesis, where their function is completely different. While the discovery that MMPs have a broad range of substrates other than ECM proteins providing new insight into the complexity of their role in tissue remodeling, it also raises numerous questions as to the mechanisms whereby the net effect of their activity is determined. Changed MMP activity is observed above all in impaired tissue. Knowledge of mechanisms of different MMP activation and inhibition may contribute to the treatment of heart diseases. MMPs and their selective synthetic inhibitors will be used not only in the treatment of various oncological diseases but also in diseases of the cardiovascular system.

\section{ACKNOWLEDGEMENT}

This work was supported by grant No. 45/2001/C GAUK and grant No. NA 6494-3/IGA MZ

\section{REFERENCES}

1. Borkakoti N. (2000) Structural studies of matrix metalloproteinases. J Mol Med. 78, 261-268.

2. Shapiro SD. (1998) Matrix metalloproteinase degradation of extracellular matrix: biological consequences. Curr Opin Cell Biol. 10, 602-608.

3. Zagris N. (2001) Extracellular matrix in development of the early embryo. Micron. 32, 427-438.

4. Birkedal-Hansen H. (1995) Proteolytic remodeling of extracellular matrix. Curr Opin Cell Biol. 7, 728-735.

5. Arthur MJ. (2000) Fibrogenesis II. Metalloproteinases and their inhibitors in liver fibrosis. Am J Physiol Gastrointest Liver Physiol. 279, G245-249.

6. Brinckerhoff CE, Rutter JL, Benbow U. (2000) Interstitial collagenases as markers of tumor progression. Clin Cancer Res. 6, 4823-4830.

7. Obermuller N, Morente N, Kranzlin B, Gretz N, Witzgall R. (2001) A possible role for metalloproteinases in renal cyst development. Am J Physiol Renal Physiol. 280, F540-550.

8. Stetler-Stevenson WG, Yu AE. (2001) Proteases in invasion: matrix metalloproteinases. Semin Cancer Biol. 11, 143-152.

9. Lee MH, Murphy G. (2004) Matrix metalloproteinases at a glance. J Cell Sci. 117, 4015-4016.

10. Ala-aho R, Kahari VM. (2005) Collagenases in cancer. Biochimie. 87, 273-286.

11. Overall CM, Lopez-Otin C. (2002) Strategies for MMP inhibition in cancer: innovations for the post-trial era. Nat Rev Cancer. 2, 657-672.

12. Becker JW, Marcy AI, Rokosz LL, Axel MG, Burbaum JJ, Fitzgerald PM, Cameron PM, Esser CK, Hagmann WK, et al. (1995) Stromelysin-1: three-dimensional structure of the inhibited 
catalytic domain and of the C-truncated proenzyme. Protein Sci. 4, 1966-1976.

13. Van Wart HE, Birkedal-Hansen H. (1990) The cysteine switch: a principle of regulation of metalloproteinase activity with potential applicability to the entire matrix metalloproteinase gene family. Proc Natl Acad Sci U S A. 87, 5578-5582.

14. Stocker W, Gomis-Ruth FX, Bode W, Zwilling R. (1993) Implications of the three-dimensional structure of astacin for the structure and function of the astacin family of zinc-endopeptidases. Eur J Biochem. 214, 215-231.

15. Dhanaraj V, Ye QZ, Johnson LL, Hupe DJ, Ortwine DF, Dunbar JB, Jr., Rubin JR, Pavlovsky A, Humblet C, et al. (1996) X-ray structure of a hydroxamate inhibitor complex of stromelysin catalytic domain and its comparison with members of the zinc metalloproteinase superfamily. Structure. 4, 375-386.

16. Gomis-Ruth FX, Gohlke U, Betz M, Knauper V, Murphy G, Lopez-Otin C, Bode W. (1996) The helping hand of collagenase-3 (MMP-13): 2.7 A crystal structure of its C-terminal haemopexinlike domain. J Mol Biol. 264, 556-566.

17. Bode W. (1995) A helping hand for collagenases: the haemopexinlike domain. Structure. 3, 527-530.

18. Buttner FH, Hughes CE, Margerie D, Lichte A, Tschesche H, Caterson B, Bartnik E. (1998) Membrane type 1 matrix metalloproteinase (MT1-MMP) cleaves the recombinant aggrecan substrate rAgg1mut at the 'aggrecanase' and the MMP sites. Characterization of MT1-MMP catabolic activities on the interglobular domain of aggrecan. Biochem J. 333, 159-165.

19. Nagase H, Woessner JF, Jr. (1999) Matrix metalloproteinases. J Biol Chem. 274, 21491-21494.

20. Ye S. (2000) Polymorphism in matrix metalloproteinase gene promoters: implication in regulation of gene expression and susceptibility of various diseases. Matrix Biol. 19, 623-629.

21. Murphy G, Nguyen Q, Cockett MI, Atkinson SJ, Allan JA, Knight CG, Willenbrock F, Docherty AJ. (1994) Assessment of the role of the fibronectin-like domain of gelatinase $\mathrm{A}$ by analysis of a deletion mutant. J Biol Chem. 269, 6632-6636.

22. Uria JA, Lopez-Otin C. (2000) Matrilysin-2, a new matrix metalloproteinase expressed in human tumors and showing the minimal domain organization required for secretion, latency, and activity. Cancer Res. 60, 4745-4751.

23. Wilson CL, Matrisian LM. (1996) Matrilysin: an epithelial matrix metalloproteinase with potentially novel functions. Int J Biochem Cell Biol. 28, 123-136.

24. Llano E, Pendas AM, Knauper V, Sorsa T, Salo T, Salido E, Murphy G, Simmer JP, Bartlett JD, et al. (1997) Identification and structural and functional characterization of human enamelysin (MMP20). Biochemistry. 36, 15101-15108.

25. Lohi J, Wilson CL, Roby JD, Parks WC. (2001) Epilysin, a novel human matrix metalloproteinase (MMP-28) expressed in testis and keratinocytes and in response to injury. J Biol Chem. 276, 10134-10144.

26. Pendas AM, Knauper V, Puente XS, Llano E, Mattei MG, Apte S, Murphy G, Lopez-Otin C. (1997) Identification and characterization of a novel human matrix metalloproteinase with unique structural characteristics, chromosomal location, and tissue distribution. J Biol Chem. 272, 4281-4286.

27. Stracke JO, Hutton M, Stewart M, Pendas AM, Smith B, LopezOtin C, Murphy G, Knauper V. (2000) Biochemical characterization of the catalytic domain of human matrix metalloproteinase 19. Evidence for a role as a potent basement membrane degrading enzyme. J Biol Chem. 275, 14809-14816.

28. Marchenko GN, Ratnikov BI, Rozanov DV, Godzik A, Deryugina EI, Strongin AY. (2001) Characterization of matrix metalloproteinase-26, a novel metalloproteinase widely expressed in cancer cells of epithelial origin. Biochem J. 356, 705-718.

29. Pei D, Majmudar G, Weiss SJ. (1994) Hydrolytic inactivation of a breast carcinoma cell-derived serpin by human stromelysin-3. J Biol Chem. 269, 25849-25855.

30. Ohnishi J, Ohnishi E, Jin M, Hirano W, Nakane D, Matsui H, Kimura A, Sawa H, Nakayama K, et al. (2001) Cloning and characterization of a rat ortholog of MMP-23 (matrix metalloproteinase23 ), a unique type of membrane-anchored matrix metalloproteinase and conditioned switching of its expression during the ovarian follicular development. Mol Endocrinol. 15, 747-764.

31. Imai K, Hiramatsu A, Fukushima D, Pierschbacher MD, Okada Y. (1997) Degradation of decorin by matrix metalloproteinases: identification of the cleavage sites, kinetic analyses and transforming growth factor-beta1 release. Biochem J. 322, 809-814.

32. Prockop DJ, Kivirikko KI. (1995) Collagens: molecular biology, diseases, and potentials for therapy. Annu Rev Biochem. 64, 403434.

33. Netzel-Arnett S, Fields GB, Birkedal-Hansen H, Van Wart HE, Fields G. (1991) Sequence specificities of human fibroblast and neutrophil collagenases. J Biol Chem. 266, 6747-6755.

34. Aimes RT, Quigley JP. (1995) Matrix metalloproteinase-2 is an interstitial collagenase. Inhibitor-free enzyme catalyzes the cleavage of collagen fibrils and soluble native type I collagen generating the specific 3/4- and 1/4-length fragments. J Biol Chem. 270, 5872-5876.

35. Allan JA, Hembry RM, Angal S, Reynolds JJ, Murphy G. (1991) Binding of latent and high $\mathrm{Mr}$ active forms of stromelysin to collagen is mediated by the C-terminal domain. J Cell Sci. 99, 789795.

36. Murphy G, Allan JA, Willenbrock F, Cockett MI, O'Connell JP, Docherty AJ. (1992) The role of the C-terminal domain in collagenase and stromelysin specificity. J Biol Chem. 267, 9612-9618.

37. Knauper V, Lopez-Otin C, Smith B, Knight G, Murphy G. (1996) Biochemical characterization of human collagenase-3. J Biol Chem. 271, 1544-1550.

38. De Souza SJ, Pereira HM, Jacchieri S, Brentani RR. (1996) Collagen/collagenase interaction: does the enzyme mimic the conformation of its own substrate? Faseb J. 10, 927-930.

39. Chung L, Shimokawa K, Dinakarpandian D, Grams F, Fields GB, Nagase H. (2000) Identification of the (183)RWTNNFREY(191) region as a critical segment of matrix metalloproteinase 1 for the expression of collagenolytic activity. J Biol Chem. 275, 2961029617.

40. Ohuchi E, Imai K, Fujii Y, Sato H, Seiki M, Okada Y. (1997) Membrane type 1 matrix metalloproteinase digests interstitial collagens and other extracellular matrix macromolecules. J Biol Chem. 272, 2446-2451.

41. Wang Y, Johnson AR, Ye QZ, Dyer RD. (1999) Catalytic activities and substrate specificity of the human membrane type 4 matrix metalloproteinase catalytic domain. J Biol Chem. 274, 3304333049.

42. Ellerbroek SM, Wu YI, Stack MS. (2001) Type I collagen stabilization of matrix metalloproteinase-2. Arch Biochem Biophys. 390, 51-56.

43. Senior RM, Griffin GL, Fliszar CJ, Shapiro SD, Goldberg GI, Welgus HG. (1991) Human 92- and 72-kilodalton type IV collagenases are elastases. J Biol Chem. 266, 7870-7875.

44. Liu Z, Zhou X, Shapiro SD, Shipley JM, Twining SS, Diaz LA, Senior RM, Werb Z. (2000) The serpin alpha1-proteinase inhibitor is a critical substrate for gelatinase B/MMP-9 in vivo. Cell. 102, 647-655.

45. Kridel SJ, Chen E, Kotra LP, Howard EW, Mobashery S, Smith JW. (2001) Substrate hydrolysis by matrix metalloproteinase-9. J Biol Chem. 276, 20572-20578.

46. Gronski TJ, Jr., Martin RL, Kobayashi DK, Walsh BC, Holman MC, Huber M, Van Wart HE, Shapiro SD. (1997) Hydrolysis of a broad spectrum of extracellular matrix proteins by human macrophage elastase. J Biol Chem. 272, 12189-12194.

47. Stracke JO, Fosang AJ, Last K, Mercuri FA, Pendas AM, Llano E, Perris R, Di Cesare PE, Murphy G, et al. (2000) Matrix metalloproteinases 19 and 20 cleave aggrecan and cartilage oligomeric matrix protein (COMP). FEBS Lett. 478, 52-56.

48. Auble DT, Brinckerhoff CE. (1991) The AP-1 sequence is necessary but not sufficient for phorbol induction of collagenase in fibroblasts. Biochemistry. 30, 4629-4635.

49. Duivenvoorden WC, Hirte HW, Singh G. (1999) Transforming growth factor beta 1 acts as an inducer of matrix metalloproteinase expression and activity in human bone-metastasizing cancer cells. Clin Exp Metastasis. 17, 27-34. 
50. Wada K, Sato H, Kinoh H, Kajita M, Yamamoto H, Seiki M. (1998) Cloning of three Caenorhabditis elegans genes potentially encoding novel matrix metalloproteinases. Gene. 211, 57-62.

51. Nagase H, Suzuki K, Morodomi T, Enghild JJ, Salvesen G. (1992) Activation mechanisms of the precursors of matrix metalloproteinases 1, 2 and 3. Matrix Suppl. 1, 237-244.

52. Nagase H. (1998) Cell surface activation of progelatinase A (proMMP-2) and cell migration. Cell Res. 8, 179-186.

53. Spiegel S, Foster D, Kolesnick R. (1996) Signal transduction through lipid second messengers. Curr Opin Cell Biol. 8, 159167.

54. Korzus E, Nagase H, Rydell R, Travis J. (1997) The mitogen-activated protein kinase and JAK-STAT signaling pathways are required for an oncostatin M-responsive element-mediated activation of matrix metalloproteinase 1 gene expression. J Biol Chem. 272, 1188-1196.

55. Fisher GJ, Datta SC, Talwar HS, Wang ZQ, Varani J, Kang S, Voorhees JJ. (1996) Molecular basis of sun-induced premature skin ageing and retinoid antagonism. Nature. 379, 335-339.

56. Brenneisen P, Wenk J, Klotz LO, Wlaschek M, Briviba K, Krieg T, Sies H, Scharffetter-Kochanek K. (1998) Central role of Ferrous/ Ferric iron in the ultraviolet B irradiation-mediated signaling pathway leading to increased interstitial collagenase (matrix-degrading metalloprotease (MMP)-1) and stromelysin-1 (MMP-3) mRNA levels in cultured human dermal fibroblasts. J Biol Chem. 273 5279-5287.

57. Biswas C, Zhang Y, DeCastro R, Guo H, Nakamura T, Kataoka H, Nabeshima K. (1995) The human tumor cell-derived collagenase stimulatory factor (renamed EMMPRIN) is a member of the immunoglobulin superfamily. Cancer Res. 55, 434-439.

58. Lim M, Martinez T, Jablons D, Cameron R, Guo H, Toole B, Li JD, Basbaum C. (1998) Tumor-derived EMMPRIN (extracellular matrix metalloproteinase inducer) stimulates collagenase transcription through MAPK p38. FEBS Lett. 441, 88-92.

59. Li YY, McTiernan CF, Feldman AM. (2000) Interplay of matrix metalloproteinases, tissue inhibitors of metalloproteinases and their regulators in cardiac matrix remodeling. Cardiovasc Res. 46 214-224.

60. Xie B, Laouar A, Huberman E. (1998) Fibronectin-mediated cell adhesion is required for induction of $92-\mathrm{kDa}$ type IV collagenase/ gelatinase (MMP-9) gene expression during macrophage differentiation. The signaling role of protein kinase C-beta. J Biol Chem. $273,11576-11582$

61. Seltzer JL, Lee AY, Akers KT, Sudbeck B, Southon EA, Wayner EA, Eisen AZ. (1994) Activation of 72-kDa type IV collagenase/ gelatinase by normal fibroblasts in collagen lattices is mediated by integrin receptors but is not related to lattice contraction. Exp Cell Res. 213, 365-374.

62. Lijnen HR, Lupu F, Moons L, Carmeliet P, Goulding D, Collen D. (1999) Temporal and topographic matrix metalloproteinase expression after vascular injury in mice. Thromb Haemost. 81, 799-807.

63. Springman EB, Angleton EL, Birkedal-Hansen H, Van Wart HE. (1992) Biochemical basis for multiple modes of activation of human fibroblast collagenase. Matrix Suppl. 1, 76-77.

64. Nagase H. (1997) Activation mechanisms of matrix metalloproteinases. Biol Chem. 378, 151-160.

65. Suzuki K, Enghild JJ, Morodomi T, Salvesen G, Nagase H. (1990) Mechanisms of activation of tissue procollagenase by matrix metalloproteinase 3 (stromelysin). Biochemistry. 29, 10261-10270.

66. Suzuki K, Lees M, Newlands GF, Nagase H, Woolley DE. (1995) Activation of precursors for matrix metalloproteinases 1 (interstitial collagenase) and 3 (stromelysin) by rat mast-cell proteinases I and II. Biochem J. 305, 301-306.

67. Suzuki D, Miyazaki M, Jinde K, Koji T, Yagame M, Endoh M, Nomoto Y, Sakai H. (1997) In situ hybridization studies of matrix metalloproteinase-3, tissue inhibitor of metalloproteinase-1 and type IV collagen in diabetic nephropathy. Kidney Int. 52, 111-119.

68. Okada Y, Morodomi T, Enghild JJ, Suzuki K, Yasui A, Nakanishi I, Salvesen G, Nagase H. (1990) Matrix metalloproteinase 2 from human rheumatoid synovial fibroblasts. Purification and activa- tion of the precursor and enzymic properties. Eur J Biochem. 194, 721-730.

69. Sato H, Takino T, Okada Y, Cao J, Shinagawa A, Yamamoto E, Seiki M. (1994) A matrix metalloproteinase expressed on the surface of invasive tumour cells. Nature. 370, 61-65.

70. Strongin AY, Collier I, Bannikov G, Marmer BL, Grant GA, Goldberg GI. (1995) Mechanism of cell surface activation of 72$\mathrm{kDa}$ type IV collagenase. Isolation of the activated form of the membrane metalloprotease. J Biol Chem. 270, 5331-5338.

71. Murphy G. (1995) Matrix metalloproteinases and their inhibitors. Acta Orthop Scand Suppl. 266, 55-60.

72. Springman EB, Angleton EL, Birkedal-Hansen H, Van Wart HE. (1990) Multiple modes of activation of latent human fibroblast collagenase: evidence for the role of a Cys 73 active-site zinc complex in latency and a "cysteine switch" mechanism for activation. Proc Natl Acad Sci U S A. 87, 364-368.

73. Kolkenbrock H, Orgel D, Hecker-Kia A, Noack W, Ulbrich N (1991) The complex between a tissue inhibitor of metalloproteinases (TIMP-2) and 72-kDa progelatinase is a metalloproteinase inhibitor. Eur J Biochem. 198, 775-781.

74. Kolkenbrock H, Hecker-Kia A, Orgel D, Ruppitsch W, Ulbrich N. (1994) Activity of ternary gelatinase A-TIMP-2-matrix metalloproteinase complexes. Biol Chem Hoppe Seyler. 375, 589-595.

75. Ogata Y, Itoh Y, Nagase H. (1995) Steps involved in activation of the pro-matrix metalloproteinase 9 (progelatinase B)-tissue inhibitor of metalloproteinases-1 complex by 4-aminophenylmercuric acetate and proteinases. J Biol Chem. 270, 18506-18511.

76. Ries C, Petrides PE. (1995) Cytokine regulation of matrix metalloproteinase activity and its regulatory dysfunction in disease. Biol Chem Hoppe Seyler. 376, 345-355.

77. Fabunmi RP, Baker AH, Murray EJ, Booth RF, Newby AC. (1996) Divergent regulation by growth factors and cytokines of $95 \mathrm{kDa}$ and $72 \mathrm{kDa}$ gelatinases and tissue inhibitors or metalloproteinases$1,-2$, and -3 in rabbit aortic smooth muscle cells. Biochem J. 315, 335-342.

78. Apte SS, Hayashi K, Seldin MF, Mattei MG, Hayashi M, Olsen BR. (1994) Gene encoding a novel murine tissue inhibitor of metalloproteinases (TIMP), TIMP-3, is expressed in developing mouse epithelia, cartilage, and muscle, and is located on mouse chromosome 10. Dev Dyn. 200, 177-197.

79. Anand-Apte B, Bao L, Smith R, Iwata K, Olsen BR, Zetter B, Apte SS. (1996) A review of tissue inhibitor of metalloproteinases-3 (TIMP-3) and experimental analysis of its effect on primary tumor growth. Biochem Cell Biol. 74, 853-862.

80. Tummalapalli CM, Heath BJ, Tyagi SC. (2001) Tissue inhibitor of metalloproteinase-4 instigates apoptosis in transformed cardiac fibroblasts. J Cell Biochem. 80, 512-521.

81. Hayakawa T, Yamashita K, Tanzawa K, Uchijima E, Iwata K. (1992) Growth-promoting activity of tissue inhibitor of metalloproteinases-1 (TIMP-1) for a wide range of cells. A possible new growth factor in serum. FEBS Lett. 298, 29-32.

82. Hayakawa T, Yamashita K, Ohuchi E, Shinagawa A. (1994) Cell growth-promoting activity of tissue inhibitor of metalloproteinases2 (TIMP-2). J Cell Sci. 107, 2373-2379.

83. Ponton A, Coulombe B, Skup D. (1991) Decreased expression of tissue inhibitor of metalloproteinases in metastatic tumor cells leading to increased levels of collagenase activity. Cancer Res. 51, 2138-2143.

84. Tyagi SC. (1997) Proteinases and myocardial extracellular matrix turnover. Mol Cell Biochem. 168, 1-12.

85. Maisch B. (1996) Ventricular remodeling. Cardiology. 87, 2-10.

86. Pelouch V, Jirmar R. (1993) Biochemical characteristics of cardiac collagen and its role in ventricular remodelling following infarction. Physiol Res. 42, 283-292.

87. Schacherer C, Koops D, Wiemer J, Hartmann A, Weis M, Klepzig H, Zeiher AM, Olbrich HG. (1999) Extracellular matrix structure after heart transplantation. Int J Cardiol. 68, 115-120.

88. Weber KT, Sun Y, Tyagi SC, Cleutjens JP. (1994) Collagen network of the myocardium: function, structural remodeling and regulatory mechanisms. J Mol Cell Cardiol. 26, 279-292. 
89. Jones FS, Jones PL. (2000) The tenascin family of ECM glycoproteins: structure, function, and regulation during embryonic development and tissue remodeling. Dev Dyn. 218, 235-259.

90. Ross RS, Borg TK. (2001) Integrins and the myocardium. Circ Res. 88, 1112-1119.

91. Cleutjens JP. (1996) The role of matrix metalloproteinases in heart disease. Cardiovasc Res. 32, 816-821.

92. Tyagi SC, Kumar S, Voelker DJ, Reddy HK, Janicki JS, Curtis JJ. (1996) Differential gene expression of extracellular matrix components in dilated cardiomyopathy. J Cell Biochem. 63, 185-198.

93. Tyagi SC, Campbell SE, Reddy HK, Tjahja E, Voelker DJ. (1996) Matrix metalloproteinase activity expression in infarcted, noninfarcted and dilated cardiomyopathic human hearts. Mol Cell Biochem. 155, 13-21.

94. Tyagi SC, Matsubara L, Weber KT. (1993) Direct extraction and estimation of collagenase(s) activity by zymography in microquantities of rat myocardium and uterus. Clin Biochem. 26, 191-198.

95. Tyagi SC, Ratajska A, Weber KT. (1993) Myocardial matrix metalloproteinase(s): localization and activation. Mol Cell Biochem. 126, 49-59.

96. Cleutjens JP, Kandala JC, Guarda E, Guntaka RV, Weber KT. (1995) Regulation of collagen degradation in the rat myocardium after infarction. J Mol Cell Cardiol. 27, 1281-1292.

97. Carlyle WC, Jacobson AW, Judd DL, Tian B, Chu C, Hauer KM, Hartman MM, McDonald KM. (1997) Delayed reperfusion alters matrix metalloproteinase activity and fibronectin mRNA expression in the infarct zone of the ligated rat heart. J Mol Cell Cardiol. 29, 2451-2463

98. Lindsey M, Wedin K, Brown MD, Keller C, Evans AJ, Smolen J, Burns AR, Rossen RD, Michael L, et al. (2001) Matrix-dependent mechanism of neutrophil-mediated release and activation of matrix metalloproteinase 9 in myocardial ischemia/reperfusion. Circulation. 103, 2181-2187.

99. Cheung PY, Sawicki G, Wozniak M, Wang W, Radomski MW, Schulz R. (2000) Matrix metalloproteinase-2 contributes to ischemia-reperfusion injury in the heart. Circulation. 101, 18331839.

100. Rohde LE, Ducharme A, Arroyo LH, Aikawa M, Sukhova GH, Lopez-Anaya A, McClure KF, Mitchell PG, Libby P, et al. (1999) Matrix metalloproteinase inhibition attenuates early left ventricular enlargement after experimental myocardial infarction in mice. Circulation. 99, 3063-3070.

101. Robert V, Besse S, Sabri A, Silvestre JS, Assayag P, Nguyen VT, Swynghedauw B, Delcayre C. (1997) Differential regulation of matrix metalloproteinases associated with aging and hypertension in the rat heart. Lab Invest. 76, 729-738.

102. Li YY, Feldman AM, Sun Y, McTiernan CF. (1998) Differential expression of tissue inhibitors of metalloproteinases in the failing human heart. Circulation. 98, 1728-1734.

103. Thomas CV, Coker ML, Zellner JL, Handy JR, Crumbley AJ, 3rd, Spinale FG. (1998) Increased matrix metalloproteinase activity and selective upregulation in LV myocardium from patients with end-stage dilated cardiomyopathy. Circulation. 97, 1708-1715.

104. Tyagi SC. (1998) Extracellular matrix dynamics in heart failure a prospect for gene therapy. J Cell Biochem. 68, 403-410.

105. Kukacka J, Bíbová J, Ruskoaho H, Pelouch V. (2002) Chronic hypoxia alters expression of extracellular matrix components in rat. Phys Res. 51, P21.

106. Kukacka J, Bíbová J, Ruskoaho H, Pelouch V. (2002) The effect of hypoxia and hypercapnia on remodeling of extracellular matrix in rat heart. Faseb J. 16, A1116.

107. Tyagi SC, Kumar SG, Haas SJ, Reddy HK, Voelker DJ, Hayden MR, Demmy TL, Schmaltz RA, Curtis JJ. (1996) Post-transcriptional regulation of extracellular matrix metalloproteinase in human heart end-stage failure secondary to ischemic cardiomyopathy. J Mol Cell Cardiol. 28, 1415-1428.

108. Spinale FG, Coker ML, Thomas CV, Walker JD, Mukherjee R, Hebbar L. (1998) Time-dependent changes in matrix metalloproteinase activity and expression during the progression of congestive heart failure: relation to ventricular and myocyte function. Circ Res. 82, 482-495.
109. Coker ML, Thomas CV, Clair MJ, Hendrick JW, Krombach RS, Galis ZS, Spinale FG. (1998) Myocardial matrix metalloproteinase activity and abundance with congestive heart failure. Am J Physiol. 274, H1516-1523.

110. Gunja-Smith Z, Morales AR, Romanelli R, Woessner JF, Jr. (1996) Remodeling of human myocardial collagen in idiopathic dilated cardiomyopathy. Role of metalloproteinases and pyridinoline cross-links. Am J Pathol. 148, 1639-1648.

111. Brower GL, Janicki JS. (2001) Contribution of ventricular remodeling to pathogenesis of heart failure in rats. Am J Physiol Heart Circ Physiol. 280, H674-683.

112. Botos I, Scapozza L, Zhang D, Liotta LA, Meyer EF. (1996) Batimastat, a potent matrix mealloproteinase inhibitor, exhibits an unexpected mode of binding. Proc Natl Acad Sci U S A. 93, 2749-2754.

113. Whittaker M, Floyd CD, Brown P, Gearing AJ. (2001) Design and therapeutic application of matrix metalloproteinase inhibitors. (Chem. Rev. 1999, 99, 2735-2776. Published on the web september 8, 1999). Chem Rev. 101, 2205-2206.

114. Xue CB, He X, Roderick J, DeGrado WF, Cherney RJ, Hardman KD, Nelson DJ, Copeland RA, Jaffee BD, et al. (1998) Design and synthesis of cyclic inhibitors of matrix metalloproteinases and TNF-alpha production. J Med Chem. 41, 1745-1748.

115. Li YY, Kadokami T, Wang P, McTiernan CF, Feldman AM. (2002) MMP inhibition modulates TNF-[alpha] transgenic mouse phenotype early in the development of heart failure. Am J Physiol Heart Circ Physiol. 282, H983-H989.

116. Heath EI, Grochow LB. (2000) Clinical potential of matrix metalloprotease inhibitors in cancer therapy. Drugs. 59, 1043-1055.

117. Heath EI, O'Reilly S, Humphrey R, Sundaresan P, Donehower RC, Sartorius S, Kennedy MJ, Armstrong DK, Carducci MA, et al. (2001) Phase I trial of the matrix metalloproteinase inhibitor BAY12-9566 in patients with advanced solid tumors. Cancer Chemother Pharmacol. 48, 269-274.

118. Spinale FG, Coker ML, Krombach SR, Mukherjee R, Hallak H, Houck WV, Clair MJ, Kribbs SB, Johnson LL, et al. (1999) Matrix metalloproteinase inhibition during the development of congestive heart failure: effects on left ventricular dimensions and function. Circ Res. 85, 364-376.

119. Wang W, Sawicki G, Schulz R. (2002) Peroxynitrite-induced myocardial injury is mediated through matrix metalloproteinase-2. Cardiovasc Res. 53, 165-174.

120. Peterson JT, Hallak H, Johnson L, Li H, O’Brien PM, Sliskovic DR, Bocan TM, Coker ML, Etoh T, et al. (2001) Matrix metalloproteinase inhibition attenuates left ventricular remodeling and dysfunction in a rat model of progressive heart failure. Circulation. 103, 2303-2309.

121. Li H, Simon H, Bocan TM, Peterson JT. (2000) MMP/TIMP expression in spontaneously hypertensive heart failure rats: the effect of ACE- and MMP-inhibition. Cardiovasc Res. 46, 298-306.

122. Hidalgo M, Eckhardt SG. (2001) Development of matrix metalloproteinase inhibitors in cancer therapy. J Natl Cancer Inst. 93, 178-193.

123. Golub LM, Ramamurthy N, McNamara TF, Gomes B, Wolff M, Casino A, Kapoor A, Zambon J, Ciancio S, et al. (1984) Tetracyclines inhibit tissue collagenase activity. A new mechanism in the treatment of periodontal disease. J Periodontal Res. 19, 651-655.

124. Golub LM, Lee HM, Ryan ME, Giannobile WV, Payne J, Sorsa T. (1998) Tetracyclines inhibit connective tissue breakdown by multiple non-antimicrobial mechanisms. Adv Dent Res. 12, 12-26.

125. Rodan GA, Fleisch HA. (1996) Bisphosphonates: mechanisms of action. J Clin Invest. 97, 2692-2696.

126. Ichinose Y, Migita K, Nakashima T, Kawakami A, Aoyagi T, Eguchi K. (2000) Effects of bisphosphonate on the release of MMP-2 from cultured human osteoblasts. Tohoku J Exp Med. 192, 111-118.

127. Teronen O, Heikkila P, Konttinen YT, Laitinen M, Salo T, Hanemaaijer R, Teronen A, Maisi P, Sorsa T. (1999) MMP inhibition and downregulation by bisphosphonates. Ann N Y Acad Sci. $878,453-465$. 